\title{
The relationship between functional literacy and problem-solving skills: A study on 4th-grade students
}

\author{
Mehmet Özenç * \\ Nizip Education Faculty, Gaziantep University, Gaziantep, Turkey \\ ORCID: 0000000163394092 \\ Cafer Çarkıt \\ Nizip Education Faculty, Gaziantep University, Gaziantep, Turkey
} ORCID: 0000-0003-4126-2165

\section{Article history}

\section{Received:}

08.12.2020

Received in revised form: 15.02.2021

Accepted:

18.02.2021

Key words:

Functional literacy;

Problem-solving;

Relationship;

Elementary school students
This study explored the relationship between 4th-grade students' functional literacy levels and their problem-solving skills and the effect level of students' functional literacy experiences on their problem-solving ability. Employing the quantitative research approach, relational survey design, one of the general survey designs, was used in the study. The study universe was 4th-grade students attending public elementary schools in the central districts of Gaziantep. The study was conducted on a sample of 744 th grade students who were selected by a simple random sampling method. In the study, data were collected with scales related to two different variables, functional literacy and problemsolving. Necessary approvals for the study were taken before the implementation. SPSS 15.0 package program was utilized to analyze the data. Frequency and percentage were performed to determine the demographic information of participating students; arithmetic mean, standard deviation and standard error were performed to determine the functional literacy levels and perception levels of problem-solving skills; Pearson product-moment correlation coefficient to determine the relationship between functional literacy and its sub-dimensions, and perceptions of problem-solving skills; and finally, multiple regression analysis calculations were made to determine the predictive power of functional literacy and its sub-dimensions on perceptions of problemsolving skills. According to the study results, students' functional literacy levels were at a medium level and their problem-solving skills were at a partially high level. Also, there was a positive significant relationship between the students' functional literacy levels and their problem-solving skills. Furthermore, it was determined that functional literacy and its subdimensions significantly predicted students' problem-solving skills. The study results were discussed within the framework of the related literature.

\footnotetext{
*Correspondency: mozenc38@ @otmail.com
} 


\section{Introduction}

In the 21st century, an extraordinary change and transformation have occurred so far in many areas. The intensive use of communication tools, the spread of artistic activities such as information, theater, cinema and music in the media and social media, and efforts to shape the perception world of individuals through advertising and propaganda brought the concept of literacy to the fore. Previously defined as reading and interpreting a short and simple sentence about daily life, the concept of literacy was ascribed to quite different meanings (Güneş, 2000). Involving the actions of reading and writing actions but cannot be limited to these actions, literacy is the ability to read and make sense of our world and our environment (Kelner, 2001; Altun, 2005). Literacy is the process of having the awareness for lifelong learning, developing this awareness and acquiring new skills to achieve more effective learning (OECD, 1995). According to critical theorists, literacy goes beyond sociocultural mechanisms and refers to the interpretation of events or phenomena within the framework of one's own life experiences (Clarke, 2007). While Agee (2005) defines literacy as a process forming the basis of lifelong learning, Özenç (2020: 206) stated that literacy includes different interpretation skills requiring high-level skills. The definitions emphasized that today the concept of literacy has a dynamic and constructive structure, gains meaning in a social context, and has an aspect of creating new meanings. In this context, literacy has an important place among the life skills called the 21st-century skills.

The acquisition of literacy skills is the first step of the literacy process. According to Özenç (2013), literacy is a tradition that begins with learning how to read and write but is seen as a way of an individual improving oneself by continuing for life. In developed societies, individuals' rising in their field, their promotion to competent positions and their contribution to the welfare of the society are all directly related to the level of literacy (Göktürk, 1979). In the literacy process, one should demonstrate the ability to make sense of, analyze and criticize one's social context (Mayo, 2007). In this sense, literacy is a dynamic structure enabling the individual to understand him or herself first and determines the quality of the behaviors and skills he or she will exhibit. In this respect, literacy is a part and an important goal of the education process. In fact, Lankshear (1999) expressed that literacy has an important role in both the potential development of the language and reforming thought. According to this, schools' training students as functional literates is seen as a necessity for them to continue their lives effectively in today's complex world. This situation indeed highlights the concept of functional literacy.

Functional literacy is an important stage of the literacy process. Functional literacy, which can be defined as a transition from basic literacy level to operational literacy, is using the acquired knowledge and skills in individual, socio-cultural or economic areas. According to Gorman (2003), functional literacy is a literacy skill enabling individuals to live at a normal level. Güneş (1994) stated that functional literacy is an advanced literacy level helping individuals to develop their citizenship and sociocultural roles. Functional literacy is a multidimensional concept that paves the way for the development of both the individual and the society and enables the individual to transfer his or her knowledge and experience to every stage of daily life effectively and functionally (Özenç, 2012). The most important characteristics of functional literates are their ability to use reading, writing, calculating and problem-solving skills effectively (Jenning, 2000). Functionally literate people are aware of their capacities and aim to develop these abilities to the fullest. In this context, the functionally literate individuals, in other words, who can apply the knowledge they learn, are also expected to be able to solve the problems they encounter at a high level. 
Problem-solving skill is one of the characteristics that is expected the most from today's individuals because problem-solving skill is accepted as an important cognitive activity in professional business and daily life (Jonassen, 2000). Van Laar, Van Deursen, Van Dijk, and De Haan (2017) state that one of the seven basic skills that should be possessed is problemsolving. Individuals who can use problem-solving skills effectively can overcome difficulties in daily life and can develop different solutions to problems. In this sense, functional literacy is an effective way of serving the development of individuals because functionally literate people have the important characteristics of understanding complex problems and being able to overcome them (Güneş, 2000). In the process of solving a problem, one needs to go beyond the simple application of the rules learned through previous experiences and find new solutions (Korkut, 2002). At this point, functional literacy contributes to the transfer of an individual's knowledge to possible solutions to the problem and to making use of his or her experiences in this sense. According to Myrick (1993), it may not always be possible to learn effective problem-solving methods in daily life. In this case, it is necessary to teach students the ways of solving problems during the education process. The teaching activities carried out within this framework not only improve their problem-solving skills but also serve them to be literate at a functional level.

In the learning environment, teaching students functional literacy and problem-solving skills is seen as an interdisciplinary issue, but it is primarily the objective of the courses that teach native language. Concepts such as communication in the native language, communication in a foreign language, mathematical and scientific/technological competence, digital competence, cultural awareness and learning to learn with expression found in the 2019 Turkish Course Curriculum (Ministry of National Education, 2019) can be considered as the main concepts of functional literacy. Also, having objectives about the development of problem-solving skills at every grade level in the curriculum is important in terms of transferring literacy experiences to daily life. In this context, it is a necessity to reveal the relationship between students' functional literacy levels and problem-solving skills.

There are many studies on literacy in the related literature. Aş1c1 (2009) examined how literacy is defined historically. Önal (2010) investigated the factors contributing to the lifelong learning and development of literacy. Tichnor-Wagner, Garwood, Bratsch-Hines, and Vernon-Feagans, (2015) analyzed the family literacy environments and basic literacy skills of students attending elementary schools in rural areas. Ergül, Sarıca, and Akoğlu (2016) examined the effect of reading interactive books on the development of language and early literacy skills. Kargın, Güldenoğlu, and Ergül (2017) analyzed the early literacy skill profiles of kindergarten children. Duran and Özen (2018) investigated digital literacy in Turkish Language courses. In addition, while Özenç (2012) examined the relationship between functional literacy and academic achievement, Özenç and Dikici (2016) examined the relationship between functional literacy and metacognitive awareness, and Tezel and Tezgören (2019) examined the relationship between scientific literacy and problem-solving skills of 8th-grade students. Furthermore, many studies are examining the relationship of problem-solving skillswith different variables (Sayg1l1, 2000; Özsoy, 2005; Salami \& Aremu, 2006; Sharifi, 2006; Berkant \& Eren, 2013; Yang \& Sim, 2016. On the other hand, there is no study investigating the relationship between functional literacy and problem-solving skills. Unlike the studies in the literature, this study examined the relationship between the functional literacy levels of 4th grade students and their problem-solving skills and determine the effect level of students' literacy experiences with their problem-solving skills. In this context, it was aimed to reveal the effect of functional literacy activities carried out in the educational process on students' problem-solving process in their daily lives. It is expected 
that the study will contribute to the field in terms of determining the role of functional literacy activities in the context of problem-solving skills in daily life. In line with these views, the following study questions were developed:

(1) What are the 4th grade students' functional literacy and problem-solving skill levels?

(2) Is there a significant relationship between the 4th grade students' functional literacy and functional literacy sub-dimension levels (school, environment, family) and their problem-solving skills?

(3) Are 4th grade students' functional literacy levels significant predictors of their problem-solving skills?

(4) Are 4th grade students' functional literacy sub-dimension (school, environment and family) levels significant predictors of their problem-solving skills?

\section{Method}

In this section, the study design, universe and sample, data collection tools and data analysis are discussed and explained.

\section{Study Design}

Aiming to reveal the relationship between 4th grade students' functional literacy levels and their problem-solving skills, this study employed the survey design. Survey design aims to meticulously and thoroughly describe a situation or a phenomenon that participants have previously experienced or still experiencing (Karasar, 2014). The survey design describes the current situation of a subject. In survey design, data on situations with more than one feature can be collected and the relationship level between them can be questioned. In this method, in order to examine the relationship between two or more variables, these variables are examined without interfering with them in any way (Büyüköztürk, Kılıç-Çakmak, Akgün, Karadeniz, \& Demirel, 2014). In this study, it was aimed to determine the relationship between 4th grade students' functional literacy levels and their perceptions of problemsolving skills. Accordingly, scales were administered to determine both variables, and the relationship level of these variables was determined by performing the necessary statistical analyses.

\section{Universe and Sample}

In quantitative studies, it is aimed to form a satisfactory sample by the spirit of the research from the researched universe (Cohen, Manion, \& Marrison, 2007; Fraenkel, Wallen, \& Hyun, 2009). The study universe was 4th grade students attending public elementary schools in the central districts of Gaziantep. This study was conducted with a sample determined by simple random sampling method, one of the random sampling methods, because of the size of the population, economic difficulty, and difficulties in transportation and regarding time. The study data were collected from 744 th grade students. The demographic information of the sample is presented below.

Table 1. Demographic Information of Students in the Sample

\begin{tabular}{llll}
\hline Demographic Characteristics & & f & $\%$ \\
\hline \multirow{2}{*}{ Sex } & Female & 380 & 51.10 \\
& Male & 364 & 48.90 \\
Having Preschool Education & Yes & 591 & 79.80 \\
& No & 150 & 20.20 \\
& & Participatory Educational Research (PER) (PER)
\end{tabular}




\begin{tabular}{llll} 
& Between 1-2 & 591 & 79.80 \\
Number of Siblings & Between 3-4 & 127 & 17.10 \\
& 5 and above & 23 & 3.10 \\
Mother's Education Level & Elementary School & 128 & 17.40 \\
& Middle School & 180 & 24.50 \\
& High School & 227 & 30.90 \\
Father's Education level & University and above & 200 & 27.20 \\
& Elementary School & 68 & 9.30 \\
& Middle School & 188 & 25.60 \\
& High School & 220 & 29.90 \\
& University and above & 259 & 35.20 \\
\hline
\end{tabular}

According to Table 1, 51.1\% (380) of the students participating in the study were female, and $48.9 \%$ (364) were male. $79.80 \%$ (591) of them received pre-school education, whereas $20.20 \%$ (150) of them did not. $79.80 \%$ (591) of them had 1-2 siblings, $17.10 \%$ (127) had 3-4, and $3.10 \%$ (23) had 5 or more. $17.40 \%$ (128) of the students' mothers graduated from elementary school, $24.50 \%$ (180) from middle school, 30.90\% (227) from high school and $27.20 \%$ (200) from university and above. 9.30\% (68) of the students' fathers graduated from elementary school, $25.60 \%$ (188) from middle school, 29.90\% (220) from high school and $35.20 \%$ (259) from university and above.

\section{Data Collection Tools}

In the study, data on two different variables, functional literacy and problem-solving, were collected. The "Functional Literacy Experience Scale Based on Ecological Theory" developed by Özenç (2012) to determine the functional literacy levels of students and the "Problem-solving Inventory for Children at the Level of Primary Education" developed by Serin, Bulut-Serin, and Saygilı (2010) to determine problem-solving skills. The necessary permissions needed to administer the scales were obtained.

\section{Functional Literacy Experience Scale Based on Ecological Theory}

Developed by Özenç (2012) to determine the functional literacy experiences of elementary school students, Functional Literacy Experience Scale Based on Ecological Theory (FLESBET) is a 32-item 3-point Likert-type scale with three dimensions, scored as "Never" (1), "Sometimes" (2) and "Generally" (3). Exploratory factor analysis (EFA) was performed to calculate the construct validity of the scale. The condition for performing EFA is to have a certain correlation/relationship between the variables. In this sense, Bartlett's test of sphericity was performed, and Kaiser-Meyer-Olkin (KMO) value was calculated. As a result of the statistical analyses, the KMO value was calculated as .819, and Bartlett's test of sphericity was found significant. Accordingly, the factor analysis of the scale was carried out, and the items with factor load below .35 were removed from the scale by axis rotation three times. As a result of the analyses, three sub-factors consisting of 32 items were found. In this context, the first factor of the scale consisting of 14 items was named school, the second factor consisting of seven items was named environment, and the third factor consisting of 11 items was named family. Cronbach's alpha coefficient was calculated for the internal consistency reliability of the scale, and this value for the overall scale was found .868 . Cronbach's alpha value for the first factor was $.836, .747$ for the second factor and .746 for the third factor. These values show that the internal consistency reliability of the scale is sufficient. Cronbach's alpha values calculated as a result of the reliability analysis carried out 
within the scope of this study were found .754 for the family sub-dimension, .759 for the school sub-dimension, .663 for the environment sub-dimension, and .860 for the overall scale.

\section{Problem-solving Inventory for Children at the Level of Primary Education (PSIC)}

Developed by Serin, et al. (2010) to determine the problem-solving skills perceptions of elementary school students, Problem-solving Inventory for Children at the Level of Primary Education (PSIC) is a 24-item 5-point Likert-type scale with three dimensions, scored between 1-5. Exploratory factor analysis (EFA) was employed to determine the construct validity of the scale and Confirmatory factor analysis (CFA) to test the accuracy of the structure obtained accordingly. The values of $\mathrm{x}^{2}=621.05, \mathrm{df}=249, \mathrm{x}^{2} / \mathrm{df}=2.49$, RMSEA=.051, NNFI=.87, CFI=.90, GFI $=.92$ and $\mathrm{AGFI}=.90$ confirmed that the factor structure of the scale was fit. The first factor of the scale consisting of 12 items was named confidence in problem-solving skills, the second factor consisting of seven items was named self-control, and the third factor consisting of five items was named avoidance. Cronbach's alpha coefficient was calculated for the internal consistency reliability of the scale, and this value for the overall scale was found as .80 . Cronbach's alpha value was .85 for the first factor,.78 for the second factor, and .66 for the third factor. These values show that the internal consistency reliability of the scale is sufficient. As a result of the reliability analysis carried out within the scope of this study, the Cronbach's alpha value calculated was found.83 for the overall scale.

\section{Data Analysis}

SPSS 15.0 package program was used to analyze the data. Frequency and percentage were performed to determine the demographic information of participating students; arithmetic mean, standard deviation and standard error were performed to determine the functional literacy levels and perception levels of problem-solving skills; Pearson productmoment correlation coefficient to determine the relationship between functional literacy and its sub-dimensions, and perceptions of problem-solving skills; and finally, multiple regression analysis calculations were made to determine the predictive power of functional literacy and its sub-dimensions on perceptions of problem-solving skills.

In order to perform the regression analysis, the assumptions of no outliers, linearity, multicollinearity, normal distribution (normality) of error terms, a variance of error terms being constant (covariance) and no relationship between error terms should be met (Durmuş, Yurtkoru \& Çinko, 2011: 155). In order to determine the outliers in the data set, " $z$ " values of the scale items were calculated. Boxplot chart was also examined. The three outliers' values whose " $z$ " value was not between +3 and -3 and which were outside the normal distribution according to the Boxplot chart were removed from the data set. According to the correlation analysis done to meet the linearity assumption and the scatter graphics, there was a linear relationship between perception levels of functional literacy and problem-solving skills. The correlation between independent variables is less than .70, the VIF values being less than 10, and the condition index being less than 30 indicate that there was no multicollinearity problem (Durmuş et al., 2011). Kurtosis and skewness values were calculated for the normality distribution. These values' being between the range of +1.5 and -1.5 indicates that the data were normally distributed (Tabachnick \& Fidell, 2013). According to the scatter plot drawn, the assumptions of no relationship between covariance and error terms were met. 


\section{Findings}

The main purpose of the study was to determine the relationship between 4th grade students' functional literacy levels and their problem-solving skills. The findings obtained from the analysis of the data collected within the scope of the study are presented in tables in line with the study questions. In this context, analysis and findings for the sub-problem of "What are the 4th grade students' functional literacy and problem-solving skill levels?" are presented in Table 2 .

Table 2. Arithmetic Mean, Standard Deviation and Standard Error Values Regarding Functional Literacy and Problem-solving Skill Levels $(\mathrm{N}=744)$

\begin{tabular}{lllc}
\hline \multicolumn{1}{c}{ Variables } & $\overline{\mathrm{X}}$ & SS & Std. Error \\
\hline Functional Literacy & 2.22 & .30 & .01 \\
Perception of Problem-solving Skill & 3.69 & .55 & .02 \\
\hline
\end{tabular}

In the interpretation of the arithmetic mean scores in Table 2, the FLESBET being a 3-point Likert type scale and the PSIC being a 5-point Likert type scale were taken into consideration. Accordingly, the functional literacy of the students participating in the study was found to be at a medium level $(\mathrm{X}=2.22)$ and their problem-solving skills were found to be at a partially high level $(\bar{X}=3.69)$.

The second question in the study was "Is there a significant relationship between the 4th grade students' functional literacy and functional literacy sub-dimension levels (school, environment, family) and their problem-solving skills?" Analysis and findings regarding the second sub-problem are presented in Table 3.

Table 3. Pearson Product-Moment Correlation Coefficients between Functional Literacy and Its Sub-Dimensions, and Problem-solving Skills ( $\mathrm{N}=744)$

\begin{tabular}{llllll}
\hline Variables & $\mathbf{1}$ & $\mathbf{2}$ & $\mathbf{3}$ & $\mathbf{4}$ & $\mathbf{5}$ \\
\hline 1. Family & 1 & & & & \\
2. School & $.491^{* *}$ & 1 & & & \\
3. Environment & $.580^{* *}$ & $.470^{* *}$ & 1 & & \\
4. Functional Literacy & $.834^{* *}$ & $.853^{* *}$ & $.760^{* *}$ & 1 & \\
5. Problem-solving Skills & $.466^{* *}$ & $.410^{* *}$ & $.473^{* *}$ & $.537^{* *}$ & 1 \\
\hline
\end{tabular}

$* * \mathrm{p}<.001$

According to Table 3, there is a significant positive and moderate relationship between students' functional literacy and problem-solving skills $(\mathrm{r}=.537, \mathrm{p}<.001)$. In addition, there is a significant positive and moderate relationship between students' problem-solving skills and functional literacy' family sub-dimension $(r=.466, p<.001)$, school sub-dimension $(r=.410, p$ $<.001)$, and environment sub-dimension $(\mathrm{r}=.473, \mathrm{p}<.001)$. This finding can be interpreted as problem-solving skills of 4th grade students increase as their functional literacy levels increase, and as problem-solving skills of 4th grade students decrease as their functional literacy levels decrease. Regression and multiple regression analyses were conducted to increase the strength of the findings and to determine whether functional literacy and its subdimensions significantly predict problem-solving skills of students and, if so, to determine their predictive powers.

The third question in the study was "Are 4th grade students' functional literacy levels significant predictors of their problem-solving skills?" Analysis and findings regarding the third sub-problem are presented in Table 4. 
Table 4. Regression Analysis Results Regarding the Functional Literacy's Prediction of Problem-solving Skills

\begin{tabular}{llllllll}
\hline Variable & $\mathrm{B}$ & Std. Error & $\boldsymbol{\beta}$ & $\mathrm{t}$ & $\mathrm{p}$ & Tolerance & $\mathrm{VIF}$ \\
\hline $\begin{array}{l}\text { Constant } \\
\begin{array}{l}\text { Functional Literacy } \\
\text { Levels }\end{array}\end{array}$ & 35.99 & 3,06 & - & 11,75 & .000 & - & - \\
\hline
\end{tabular}

Predicted variable: Problem-solving skills

$\mathrm{R}=.537, \mathrm{R} 2=.289$, corrected $\mathrm{R} 2=.288, \mathrm{~F}(1,742)=301.226, \mathrm{p}<.001$

According to Table 4, functional literacy levels significantly predict students' problemsolving skills $(\beta=.54, \mathrm{t}=17.36, \mathrm{~F}=301.226, \mathrm{p}<.001)$. A 1-unit increase in students' functional literacy levels will create a .54-unit increase in problem-solving skills. Functional literacy levels explain $28.8 \%$ (corrected $\mathrm{R} 2=.288, \mathrm{p}<.001$ ) of students' problem-solving skills. Based on this finding, it can be stated that the increase in the functional literacy levels of the students will also increase their problem-solving skills.

The fourth question in the study was "Are 4th grade students' functional literacy subdimension (school, environment, and family) levels significant predictors of their problemsolving skills?" Analysis and findings regarding the fourth sub-problem are presented in Table 5.

Table 5. Regression Analysis Results Regarding the Functional Literacy Sub-Dimensions' Prediction of Problem-solving Skills

\begin{tabular}{llllllll}
\hline Variable & $\mathrm{B}$ & Std. Error & $\boldsymbol{\beta}$ & $\mathrm{t}$ & $\mathrm{p}$ & Tolerance & VIF \\
\hline Constant & 34.34 & 3.09 & & 11.13 & 0.00 & & \\
Family & 0.75 & 0.13 & 0.23 & 5.83 & 0.00 & 0.60 & 1.66 \\
School & 0.47 & 0.10 & 0.18 & 4.81 & 0.00 & 0.71 & 1.41 \\
Environment & 1.30 & 0.20 & 0.26 & 6.56 & 0.00 & 0.62 & 1.62 \\
\hline
\end{tabular}

Predicted variable: Problem-solving skills

$\mathrm{R}=.55, \mathrm{R}^{2}=.30$, corrected $\mathrm{R}^{2}=.30, \mathrm{~F}(3,740)=106.18, \mathrm{p}<.001$

According to Table 5, students' problem-solving skills were significantly predicted by functional literacy's sub-dimensions of family $(\beta=.23, \mathrm{t}=5.83, \mathrm{p}<.001)$, sub-dimension of $\operatorname{school}(\beta=.18, \mathrm{t}=4.81, \mathrm{p}<.001)$, and sub-dimension of environment $(\beta=.26, \mathrm{t}=6.56, \mathrm{p}<.001)$. Based on these findings, a 1-unit increase in functional literacy's family sub-dimension will create a .23-unit increase in students' problem-solving skills, a 1-unit increase in functional literacy's school sub-dimension will create a .18-unit increase in students' problem-solving skills, and finally, a 1-unit increase in functional literacy's environment sub-dimension will create a .26-unit increase in students' problem-solving skills. According to the analysis results, $30 \%$ of students' problem-solving skills is explained by functional literacy's subdimensions of family, school and environment (corrected $\mathrm{R} 2=.30, \mathrm{p}<.001$ ). Based on this finding, it can be stated that family, school and environment, the sub-dimensions of functional literacy, all contribute to the development of students' problem-solving skills.

\section{Conclusions, Discussion and Recommendations}

In this study, the relationship between 4th grade students' functional literacy levels and their problem-solving skills was examined. For this purpose, first, students' functional literacy levels and their perception levels of problem-solving skills were determined. According to the study findings, the functional literacy levels of the students participating in the study were at a medium level. With their responses to the functional literacy scale, the 
students demonstrated that they were moderately functional literates in their families, schools and environments. There are similar study results in the literature. In her study, Özenç (2012) found functional literacy of 4th and 5th grade students at medium level. Again, Özenç and Dikici (2016) revealed that 4th grade students' functional literacy was medium. Unlike these studies, Glušac, Pilipovic, and Milic (2020) determined that the functional literacy of 3rd grade secondary school students was at a disturbing level. In their study examining the early literacy skills of kindergarten children, Kargin et al. (2017) put forth that children were close to the expected level only in the field of vocabulary, which is among the skills considered within the scope of early literacy skills, and that they did not meet the expected achievement targets in all other areas. The results of the current study and other results from the literature indicate that the students can transfer the knowledge they have learned to daily life at a moderate level and cannot increase it to the upper level. Based on this, it is important to carry out educational activities aimed at developing functional literacy skills of students starting from kindergarten. It can be said that raising the functional literacy levels of students to high levels is based on the educational activities to be carried out in the pre-school period.

The study findings also showed that students' problem-solving skill levels were at a relatively high level. According to the literature, there are similar study results. In line with the findings of the present study, Paf (2019) found that middle school students' perception levels of creative problem-solving skills were high. Likewise, Özdemir, Duran, and Kaplan (2016) determined in their study that 3rd and 4th grade students' perceptions of problem-solving skills were at a relatively high level. In addition, in their study conducted through computer games, i.e., through student application, Shute, Wang, Greiff, Zhao, \& Moore (2016) put forth that 7 th grade students have moderate problem-solving skill. The study carried out with the application method towards problem-solving differs from perception studies. In the perception studies conducted, it may be normal for students to think that they have high level problem-solving skills. In studies based on applications, it is seen that students have moderate problem-solving skills. In this respect, this study supports the studies on the perception level of students in the literature on problem-solving skills.

According to the results of the study analyses, there was a positive significant relationship between students' functional literacy levels and their problem-solving skills. Accordingly, it can be said that the higher the functional literacy levels of the students, the higher their problem-solving skills are. In other words, as the functional literacy levels of the students decrease, their problem-solving skills decrease. There are similar study results in the literature. Sümen and Çalışıcı (2016) found a significant relationship amongst teacher candidates' problem-solving skills, metacognitive awareness, and mathematics literacy. Özenç and Dikici (2016) revealed a moderate and positive relationship between 4th grade students' literacy levels and their metacognitive awareness. Metacognition enables the problem solver to strategically code the problem, develop a mental scheme, choose and plan an appropriate strategy to achieve the goal, and recognize and overcome challenges along the way. In this sense, metacognition arguably increases people's problem-solving skills (Davidson \& Sternberg, 1998 cited in Sümen \& Çalış1c1, 2016: 12). The fact that students' problem-solving skills are high indicates that their metacognitive awareness is also high. There is a positive relationship between metacognitive awareness and functional literacy (Sümen \& Çalışıcı, 2016). These results show that problem-solving skills and functional literacy level may also be related. With this study, the existence of the aforementioned relationship was also revealed. Functional literacy refers to the implementation of the knowledge, skills and experience gained. Problem-solving skills will be needed during the implementation of the information learned from family, school and environment. Using 
problem-solving skills during this process will strengthen functional literacy skills.

The present study determined that functional literacy levels are significant predictors of students' problem-solving skills. In other words, the increase in the functional literacy level of the students is an indicator showing that their problem-solving skills will also increase. In their study, Lai, Wilson, Mcnaughton, \& Hsiao (2014) put forth that a program including a literacy intervention significantly increased students' reading achievement and their preparatory qualifications for middle school compared to other students who were not a part of the literacy intervention. In other words, the researchers concluded that the increase in literacy levels of the students enabled them to start middle school more readily. The existence of problem-solving skills among the preparatory qualifications for middle school is considered important in terms of supporting this study result. Enerem (2018) stated that it is important for children to acquire early literacy skills so that they can establish cause-effect relationships and develop creative and problem-solving skills. Dreher, Smith, Kibby, \& Mikulecky (2000) argued that workplace literacy and problem-solving will be synonymous in the 21st century. Likewise, Agee (2005) stated that young people need to improve their literacy skills and that young people with advanced reading, writing and understanding skills can be competitive employment wise in the future. These results presented in the literature together with the result obtained from the present study reveal that functional literacy is an important determinant of students' problem-solving skills.

According to the analysis results in the present study, the sub-dimensions of functional literacy, the family, school and the environment, are significant predictors of problem-solving skills. Accordingly, if there is an increase in the functional literacy levels of the students regarding the family, school and environment sub-dimensions, there will be an increase in their problem-solving skills. Wüstenberg, Greiff, Vainikainen, and Murphy (2016) determined in their study with 6th grade students that the classroom environment was an important precursor of complex problem-solving skills. Kargin et al., (2017) concluded in their study that the early literacy skills of children in the preschool period are generally below expectations. In this context, the functional literacy level and problem-solving skill of the child with low literacy skills will also be at a lower level. In this sense, the problem-solving skills of students should be increased with functional literacy work that will be carried out in the family, school and environment in the early period. In the conclusion part of his study, Agee (2005) pointed out that there is an urgent need for literacy in most countries of the world, that developing technology requires more and more advanced reading skills, and that there is a large mass of people in developing countries who are illiterate and who do not sufficiently benefit from the gains of technology, having no basis for continuing lifelong learning. In this context, based on both the findings of this study and other research results in the literature, it can be stated that functional literacy and problem-solving skills will play a key role in students' future lives and that the necessary planning work should be carried out and implemented in a quick fashion for students to acquire these skills and actively use them in their daily lives.

Based on the results of the present study, the following recommendations are provided for the practitioners and other researchers.

- Functional literacy and problem-solving-skills are skills that can be developed. According to the results of this research, functional literacy of the students was found to be at a medium level. Planned work should be carried out at home and at school to develop these skills accordingly. 
- Seminars for families can go hand-in-hand with the work that will improve functional literacy and problem-solving skills.

- Practical workshops for teachers on how to improve functional literacy and problemsolving skills can be held.

- This study was conducted with 4th grade students. The relationship between functional literacy and problem-solving skills of students at different education levels can be examined.

- Examining the relationship between students' functional literacy levels and problemsolving skills, this study employed the survey design. An experimental study can be conducted to examine the effect of students' functional literacy on problem-solving skills.

- Action studies can be conducted to improve students' functional literacy and problemsolving skills.

\section{References}

Agee, J. (2005). Literacy, aliteracy, and lifelong learning. New Library World, 106 (5/6), 244252. https://doi.org/10.1108/03074800510595850

Altun, A. (2005). Gelişen teknolojiler ve yeni okuryazarlıklar [Emerging technologies and new literacy]. Ankara: Anı publishing.

Aşıcı, M. (2009). Kişisel ve sosyal bir değer olarak okuryazarlık [Literacy as a personal and social value]. Journal of Values Education, 7 (17), 9-26.

Berkant, H.G. \& Eren, İ. (2013). Investigating problem-solving skills of students of primary school math teaching department in terms of some variables. The Journal of Academic Social Science Studies International Journal of Social Science, 6 (3), 1021-1041.

Büyüköztürk, Ş., Kılıç-Çakmak, E., Akgün, Ö. E., Karadeniz, Ş. \& Demirel, F. (2014). Bilimsel araştırma yöntemleri [Scientific research methods]. Ankara: Pegem publishing.

Clarke, S. (2007). The trajectory of political education in English schools: The rise and fall of two initiatives. Citizenship Teaching and Learning, 3(1), 3-16.

Cohen, L., Manion, L. \& Morrison, K. (2007). Research methods in education. London New York: Routledge Falmer.

Duran, E. \& Özen, N. E. (2018). Türkçe derslerinde dijital okuryazarlık [Digital literacy in Turkish lessons]. Turkey Education Journal, 3(2), 31-46. https://dergipark.org.tr/tr/pub/turkegitimdergisi/issue/41487/464125

Durmuş, B., Yurtkoru, E. S. \& Çinko, M. (2011). Sosyal bilimlerde SPSS'le veri analizi [Data analysis with SPSS in social sciences]. İstanbul: Beta publishing.

Dreher, M. J., Smith, M., Kibby, M. W. \& Mikulecky, L. (2000). What will be the demands of literacy in the workplace in the next millennium. Reading Research Quarterly, $35(3), 378-383$.

Enerem, D. (2018). 60-72 ay arası çocuklarda erken okuryazarlı becerilerinin çeşitli değişkenler açisından incelenmesi [An analysis of early literacy skills in children between 60-72 months in terms of various variables] (Unpublished master thesis). Maltepe University, İstanbul.

Ergül, C., Dolunay-Sarıca, A. \& Akoğlu, G. (2016). Etkileşimli kitap okuma: Dil ve erken okuryazarlık becerilerinin geliştirilmesinde etkili bir yöntem [Dialogic reading: An effective method to improve language and early literacy skills]. Ankara University Faculty of Educational Sciences Journal of Special Education, 17 (2), 193-204.

Fraenkel, J. R., Wallen, N. E. \& Hyun, H. H. (2009). How to design and evaluate research in education. New York: McGraw-Hill. 
Glušac, T., Pilipović, V. \& Milić, M. (2020). Critical thinking skils of third grade secondary school students as a component of their functional literacy. TEME, 6 (2), 355-380.

Gorman, M. (2003). Enduring library: Technology, tradition, and the quest for balance. American Library Association, Chicago, IL.

Göktürk, A. (1979). Okuma uğraşı [Reading engagement]. İstanbul: Çağdaş publishing.

Güneş, F. (1994). Okuryazarlık kavramı ve düzeyleri [The concept and levels of literacy]. Ankara University Journal of Faculty of Educational Sciences, 27(2), 499-507.

Güneş, F. (2000).Okuma-yazma ögretimi ve beyin teknolojisi [Teaching literacy and brain technology]. Ankara: Ocak publishing.

Jenning, Z. (2000). Functional literacy of young Guyanese adults. International Review of Education, 46(1/2), 93-116.

Jonessen, D. H. (2000). Toward a design theory of problem-solving. Educational Technology Research and Development, 48, 63-85.

Karasar, N. (2014). Bilimsel araştırma yöntemi [Scientific research method]. Ankara: Nobel publishing.

Kargın, T., Güldenoğlu, B. \& Ergül, C. (2017). Early literacy profile of kindergarten children: Ankara sample. Ankara University Faculty of Educational Sciences Journal of Special Education, 18, 1-27.

Kellner, D. (2001). New technologies/new literacies: Reconstructing education fort the new millennium. International Journal of Technology and Design Education, 11, 67-81.

Korkut, F. (2002). Lise öğrencilerinin problem çözme becerileri [Problem-solving skills of high school students]. Hacettepe University Journal of Education, 22, 177-184.

Lai, M., Wilson, A., Mcnaughton, S. \& Hsiao, S. (2014). Improving achievement in secondary schools: Impact of a literacy project on reading comprehension and secondary school qualifications. Reading Research Quarterly, 49 (3), 305-334.

Lankshear, C. (1999). Literacy studies in education: Disciplined developments in a postdisciplinary age. Publised in M. Peters (Ed.), After the Disciplines. Grenwood Press.

Mayo, P. (2007). Critical approaches to education in the work of Lorenzo Milani and Paulo Freire. Studies in Philosophy and Education, 26(1), 525-544.

Ministry of National Education (2019). Türkçe dersi (1-8. sınıflar) öğretim programı [Turkish lesson $\left(1-8^{\text {th }}\right.$ grades $)$ curriculum]. Ankara: MEB publishing.

Myrick, R.D. (1993). Developmental guidance and counseling: A practical approaches (2nd Edt). Educational Media Corporation.

Organisation for Economic Cooperation and Development-OECD (1995). Literacy, economy and society: Results of the first internetional literacy survey. Paris: OECD

Önal, İ. (2010). Tarihsel değişim sürecinde yaşam boyu öğrenme ve okuryazarlık: Türkiye deneyimi [Lifelong learning and literacy in process of historical change: a Turkish experience]. Information World, 11 (1), 101-121.

Özdemir, F., Duran, M. \& Kaplan, A. (2016). Investigation of middle school students' selfefficacy perceptions of visual mathematics literacy and perceptions of problemsolving skill. Journal of Theoretical Educational Science, 9(4), 532-554.

Özenç, E. G. (2012). İlköğretim beşinci sınıf öğrencilerinin işlevsel okuryazarlık düzeyleriyle akademik başarlları arasındaki ilişki [The relationship between fifth grade primary students' functional literacy levels and academic achievements] (Unpublished doctoral thesis). Marmara University, İstanbul.

Özenç, E. G. (2013). An investigation of fifth graders' functional literacy levels according to certain family variables. Journal of Theoretical Educational Science, 6 (2), 272-299.

Özenç, E. G. \& Dikici, H. (2016). The correlation between the fourth grade students' level of functional literacy and metacognitive awareness. Journal of Education and Training Studies, 4 (12), 108-117. 
Özenç, E. G. (2020). Okuryazarlık [Literacy]. E. G. Özenç ve M. Özenç (Eds.) Teaching Turkish from theory to practice in (p. 201-212). Ankara: Pegem publishing.

Özsoy, G. (2005). Problem çözme becerisi ile matematik başarısı arasındaki ilişki [The relationship between problem-solving skills and mathematical achievement]. Gazi University Journal of Gazi Educational Faculty, 25(3), 179-190.

Paf, M. (2019). Ortaokul öğrencilerinin bilişimsel düşünme becerileri ile yaratıcı problem çözme becerileri arasındaki ilişki [The relationshıp between secondary school students computational thinking skills and creative problem-solving skills] (Unpublished master thesis). Aydin Adnan Menderes University.

Salami, S. O. \& Aremu, A. O. (2006). Relationship between problem-solving ability and study behaviour among school-going adolescents in southwestern Nigeria. Electronic Journal of Research in Educational Psychology, 8(4), 139-154.

Saygıl1, H. (2000). Problem çözme becerisi ile sosyal kişisel uyum arasındaki ilişkinin incelenmesi [The examination of relationship between the skill of problem-solving and social and individual adjustment] (Unpublished master thesis). Atatürk University, Erzurum.

Serin, O., Bulut-Serin, N. \& Sayg1l1, G. (2010). Developing problem-solving inventory for children at the level of primary education (PSIC). Elementary Education Online, 9(2), 446-458.

Sharifi, D. P. (2006). The effect of problem-solving style training on the self-esteem of 12 to 13 year old students with communicational-behavioral problems in the middle-school period. Journal of Educational Innovations, 4(14), 38-63.

Shute, V. J., Wang, L., Greiff, S., Zhao, W. \& Moore, G. (2016). Measuring problem-solving skills via stealth assessment in an engaging video game. Computers in Human Behavior, 63, 106-117. https://doi.org/10.1016/j.chb.2016.05.047

Sümen, Ö. Ö. \& Çalışıcı, H. (2016). The relationships between preservice teachers' mathematical literacy self-efficacy beliefs, metacognitive awareness and problemsolving skills. Participatory Educational Research (PER), Special Issue, 11-19. https://doi.org/10.17275/per.16.spi.2.2

Tabachnick \& Fidell (2013). Using Multivariate Statistics (sixth ed.) Boston: Pearson.

Tezel, Ö. \& Tezgören, I. (2019). Sekizinci sınıf öğrencilerinin bilimsel okuryazarlık düzeyleri ile problem çözme becerileri arasındaki ilişkinin incelenmesi [Investigation of the relationship between scientific literacy levels and problem-solving skills of eighth grade students]. ESTUDAM Journal of Education, 4(2), 68-84.

Tichnor-Wagner, A., Garwood, J., Bratsch-Hines, M. \& Vernon-Feagans, L. (2015). Home literacy environments and foundational literacy skills for struggling and nonstruggling readers in rural early elementary schools. Learning Disabilities Research \& Practice, 31(1), 6-21. https://doi.org/10.1111/ldrp.12090

Van Laar, E., Van Deursen, A. J., Van Dijk, J. A., \& De Haan, J. (2017). The relation between 21st-century skills and digital skills: A systematic literature review. Computers in Human Behavior, 72, 577-588. http://dx.doi.org/10.1016/j.chb.2017.03.010

Wüstenberg, S., Greiff, S., Vainikainen, M. P. \& Murphy, K. (2016) Individual differences in students' complex problem-solving skills: How they evolve and what they imply. Journal of Educational Psychology, 108(7), 1028-1044. https://doi.org/10.1037/edu0000101

Yang, S. H. \& Sim, I. O. (2016). Relationship between problem-solving ability, critical thinking disposition, creativity, self-efficacy and nursing process competence of nursing students. Journal of the Korea Contents Association, 16(5), 612-622. https://doi.org/10.5392/JKCA.2016.16.05.612 